\title{
(Su)odnos naravne $i$ sakramentalne ženidbe prema pobudnici Amoris laetitia
}

\author{
Anton TAMARUT* \\ https://doi.org/10.31823/d.28.3.6 \\ UDK: 27-31-555 • Pregledni članak \\ Primljeno: 12. prosinca 2019. • Prihvaćeno: 8. rujna 2020.
}

Sažetak: U članku se prikazuje i analizira (su)odnos naravne i sakramentalne ženidbe prema pobudnici Amoris laetitia. $U$ prvom poglavlju upozorava se na činjenicu da je sâmo evandelje obitelji, unutar kojega ženidbeni savez zauzima središnje mjesto, povijesna i eshatološka stvarnost; ono ima svoju naravnu i sakramentalnu razinu, svoju reljefnu i dinamičnu povijest, postupni rast i razvoj. U drugom se poglavlju prikazuje $i$ analizira čovjekova bogolikost u kojoj se nalazi temelj naravne ženidbe. Izraz slika Božja dovodi se u izravnu vezu

${ }^{*}$ Prof. dr. sc. Anton Tamarut, Katolički bogoslovni fakultet Sveučilišta u Zagrebu, Vlaška ulica 38, p. p. 432, 10000 Zagreb, Hrvatska, tamaruta@kbf.hr s parom »muško i žensko «. U trećem poglavlju upozorava se na grijeh, odnosno na Kristovo otajstvo spasenja kao osnovu za razumijevanje sakramentalnosti ženidbe. Upućuje se na središnje značenje Isusa Krista - slike Božje u obnovi braka i obitelji, podrobnije se analizira sakramentalno značenje braka i obitelji. Sakrament ženidbe promatra se pod vidom dara, znaka i poziva, odnosno poslanja. Četvrto poglavlje posvećeno je samomu (su)odnosu izmedu naravne i sakramentalne ženidbe. Naravna ženidba u odnosu prema sakramentalnoj promatra se kao prirodni, naravni temelj, otvoreni početak, kao »sjeme koje još čeka da sazrije« (AL, br. 76), odnosno kao klica »koju treba pratiti prema sakramentu ženidbe« (AL, br. 293).

Ključne riječi: naravna ženidba, sakramentalna ženidba, obitelj, čovjek - slika Božja, Presveto Trojstvo, Isus Krist, Crkva. 


\section{Uvod}

U ovom radu želimo pomno iščitati, analizirati i što je moguće točnije prikazati (su) odnos naravne i sakramentalne ženidbe prema pobudnici Amoris laetitia ${ }^{1}$. Po našem mišljenju, i tu je temu moguće pravilno obraditi i shvatiti samo ako se brine o važnim napomenama koje se tiču pobudnice u cjelini, a mogu se iščitati u svojevrsnoj preambuli dokumenta (AL, br. 1-7). Kao prvo, važno je istaknuti da je pobudnica posvećena složenoj temi koja zahtijeva daljnje slobodno produbljivanje doktrinarnih, moralnih, duhovnih i pastoralnih pitanja, a za to je svakako potreban zajednički rad pastira i teologa. U tom radu važno je sačuvati vjernost Crkvi, iskrenost, realističnost $i$ kreativnost. Cilj je dospjeti do veće jasnoće u odgovorima na brojna zahtjevna i ne baš laka pitanja. Ne samo na početku nego i kasnije na više mjesta ističe se važnost konkretne stvarnosti. Njoj naime treba posvetiti osobitu pozornost jer $\gg$ zahtjevi i pozivi Duha odzvanjaju i u samim događajima povijesti $\ll^{2}$. Pomoću tih istih događaja $\gg$ Crkva može biti vođena $k$ dubljoj spoznaji neiscrpiva otajstva braka i obitelji $\ll^{3}$.

Kao i za druga slična pitanja i probleme, tako se i za problematiku obitelji predlaže poliedar kao način, odnosno model kako pristupiti osvjetljavanju i produbljivanju teme i traženju rješenja. ${ }^{4} \mathrm{Tu}$ je još važno napomenuti kako je jubilarna godina milo-

${ }^{1}$ FRANJO, Amoris laetitia - Radost ljubavi. Posinodalna apostolska pobudnica o ljubavi u obitelji (19. III. 2016.), Zagreb, 2016. (= AL).

${ }^{2} \mathrm{AL}$, br. 31 . To je zapravo citat iz apostolske pobudnice IVANA PAVLA II. Familiaris consortio Obiteljska zajednica. Apostolska pobudnica o zadaćama kršćanske obitelji u suvremenom svijetu (22. XI. 1981.), Zagreb, 1981., br. 84 (= FC). Papa Franjo na mnogim mjestima poziva se na istu pobudnicu i općenito na nauk o braku i obitelji, odnosno na teologiju tijela Ivana Pavla II. O hermeneutici pobudnice Amoris laetitia usp. H. VARGIĆ, Amoris laetitia: vjernost ili lom? Od Wojtite do pape Franje, Zagreb, 2019., 117-124.

${ }^{3}$ AL, br. 31.

${ }^{4}$ Za model poliedra založio se papa Franjo već u svojoj programatskoj pobudnici Evangelii gaudium Radost evanđelja (2013.), gdje kaže kako za razliku od kugle »koja nije veća od svojih udaljenih dijelova, gdje je svaka točka na jednakoj udaljenosti od centra i ne postoji razlika između pojedinih točaka «, poliedar »odražava konvergenciju svih njegovih dijelova, od kojih svaki zadržava svoju originalnost « (EG, br. 236). Papa tu ponajprije misli na pastoralni rad i političko djelovanje: »I pastoralni rad i političko djelovanje nastoje u taj poliedar unijeti najbolje od svakog pojedinca. Tu ima mjesta za siromašne s njihovom kulturom, njihovim težnjama i njihovim potencijalima. Čak i osobe koje mogu biti kritizirane zbog svojih pogrešaka imaju nešto za pridonijeti što se ne smije previdjeti. To je jedinstvo narodâ koji, u univerzalnom poretku, čuvaju svoju osebujnost; to je cjelokupni zbroj osoba u društvu koje teže općem dobru u kojem doista ima mjesta za svakoga.« (Isto.) Na sliku poliedra papa Franjo vraća se i u posinodskoj apostolskoj pobudnici Cristus vivit - Krist živi [usp. FRANJO, Christus vivit - Krist živi Posinodalna apostolska pobudnica mladima i cijelome Božjem narodu (25. III. 2019.), Zagreb, 2019. $(=\mathrm{CV})]$, tamo gdje govori kako pastoral mladih $\gg$ jednostavno mora biti sinodalan, to jest sposoban oblikovati jedan 'zajednički hod' koji podrazumijeva 'vrednovanje darova koje Duh daje u skladu s pozivom i ulogom svakoga pojedinca člana [Crkve], kroz dinamizam suodgovornosti'«(CV, br. 206). $\gg N a$ taj način, učeći jedni od drugih, moći ćemo bolje izraziti onaj prekrasni poliedar što Kristova Crkva mora biti.« (CV, br. 207) 
srđa vremenski i duhovni kontekst u kojem treba promatrati i prosuđivati složenu problematiku braka i obitelji. Odgovore na brojne probleme i teška pitanja povezana s tom temom treba tražiti u svjetlu milosrđa. Ono je naime temeljno svojstvo Božje ljubavi. Tim svojstvom treba se odlikovati i ljubav u obitelji; ona također treba biti milosrdna.

Ono što općenito vrijedi za cijelu pobudnicu, vrijedi, dakako, i za njezine pojedinačne dijelove. Na osobit se način to tiče (su)odnosa naravne i sakramentalne ženidbe. Svaki je naime (su)odnos, pa tako i taj, dinamična veličina, osjetljiva i otvorena stvarnost, nikada do kraja dorečena, precizna i strogo definirana. Do toga (su)odnosa u pobudnici dolazimo postupno, u nekoliko koraka. Ponajprije upozoravamo na činjenicu da je samo evanđelje obitelji, unutar kojega ženidbeni savez zauzima središnje mjesto, povijesna i eshatološka stvarnost; ono ima svoju naravnu i sakramentalnu razinu, svoju reljefnu i dinamičnu povijest, postupni rast i razvoj. Nakon toga upozoravamo na temelje naravne ženidbe. Iz teologije slike Božje koja je jasno naznačena u pobudnici izdvajamo i ističemo bogolike dimenzije bračnoga para. $U$ daljnjem koraku pozornost je posvećena razumijevanju i značenju sakramentalnosti ženidbe. Otajstvu grijeha suprotstavljeno je otajstvo milosti, Kristovo otajstvo spasenja unutar kojega ženidbeni savez muškarca i žene poprima novu vrijednost i značenje. Tu se posebno upozorava na kristološku, ekleziološku i trinitarnu komponentu sakramenta ženidbe. $U$ zadnjem dijelu dovodi se u (su)odnos naravnu i sakramentalnu ženidbu. Upozorava se na zajedničku naravnu osnovu koja se izvodi iz teologije stvaranja, ali se istodobno ističe novost i uzvišenost sakramentalne ženidbe koja proizlazi iz Kristova otajstva spasenja. Pokazuje se naime kako poredak otkupljenja rasvjetljuje i dovršava poredak stvaranja.

\section{Evanđelje obitelji u povijesnoj i eshatološkoj perspektivi}

Prema apostolskoj pobudnici Amoris laetitia cijela je povijest svijeta označena evanđeljem obitelji. Ono započinje stvaranjem čovjeka na Božju sliku i priliku (usp. Post 1,26-27), a svoje dovršenje, odnosno puninu dosiže $\gg$ u otajstvu saveza u Kristu na kraju svijeta sa svadbom Jaganjčevom (usp. Otk 19,9) $\ll^{5}$. Evanđelje obitelji govori dakle o otajstvu saveza koje je započelo u stvaranju, na početku čovjekove povijesti s Bogom, a ispunjava se u Kristu, i to u eshatonu, Jaganjčevim svadbenim slavljem. Naime u Svetom pismu već je samo stvaranje čovjeka opisano kao svojevrsni savez s Bogom. Čovjek je primio život od Boga. Bog je njegova zaštita i sigurnost, jamac njegove sreće. Čovjek je pozvan uživati u njegovim darovima, a s druge strane čovjek je pozvan poštovati Božju zapovijed, biti Bogu poslušan i privržen. Sve dok je u zajedništvu s Bogom, čovjek živi u skladnom odnosu s drugim osobama, kao i sa

${ }^{5}$ AL, br. 63. 
svim stvorenjima koja su mu povjerena da se o njima brine, čuva ih i njeguje. $\mathrm{Na}$ sasvim osobit način životno zajedništvo muža i žene u njihovoj različitosti i jedinstvu povlašten je i jedincati prostor Božje djelatne prisutnosti. Njihov životni savez zadobiva svoju čvrstoću od njihove zajedničke povezanosti sa svojim Stvoriteljem.

U središtu evanđelja obitelji nalazi se Isus Krist. Pobudnica se otvara kristološkim ključem i jedino ju je moguće na pravilan način shvatiti u svjetlu Kristova otajstva. Isus Krist nije samo eshatološka točka punine nego je on i polazna, a zatim i sveprisutna, odnosno uzorna stvarnost svega stvorenja, po njemu i za njega je sve stvoreno (usp. Kol 1, 16), pa tako onda i bračno i obiteljsko zajedništvo osoba. Povijest otajstva braka i obitelji u znaku je Kristova otajstva, otajstva njegove ljubavi i jedinstva s Crkvom (usp. Ef 5, 25-32); na nj je usmjerena i od njega dobiva svoje puno značenje: »Ženidbeni savez, započet u stvaranju i objavljen u povijesti spasenja, prima punu objavu svoga značenja u Kristu i njegovoj Crkvi. $\ll^{6}$ Drugim riječima, prvo bračno zajedništvo, jedinstvo Adama i Eve svoju konačnu svrhu, svoj konačni i potpuni smisao dosegnut će u otajstvu jedinstva Krista, novoga Adama, sa svojom zaručnicom Crkvom, novom Evom.

U Kristu dakle poredak stvaranja i poredak otkupljenja nalaze svoje zajedničko središte, u konačnici, i svoje jedinstvo. »Poredak otkupljenja rasvjetljuje i dovršava poredak stvaranja $\ll^{7}$ te se tako naravnu ženidbu u punini može razumjeti tek u svjetlu njezina sakramentalnoga dovršenja: »tek usmjerivši pogled na Krista može se do kraja spoznati istina o ljudskim odnosima. $\ll^{8}$ Evanđelje obitelji prema tomu povijesna je i eshatološka stvarnost; ono ima svoju naravnu i svoju sakramentalnu razinu, svoju reljefnu i dinamičnu povijest, postupni rast i razvoj. Prema punini koju tek treba postići i koju se može susresti samo u kraljevstvu Božjem koje dolazi ide se, naravno, povijesnim putem, a on je pun nesavršenosti i ograničenosti. ${ }^{9}$

Što o obitelji vrijedi općenito, to se također odnosi i na obitelj u njezinoj pojedinačnosti. Naime $\gg$ nijedna obitelj nije potpuno oblikovana stvarnost ili gotov proizvod, nego treba stalno rasti i sazrijevati u sposobnosti da ljubi $\ll{ }^{10}$. Ili drugim riječima iste pobudnice: »Ne postoji stereotip idealne obitelji, nego izazovan mozaik sastavljen od više različitih stvarnosti, sa svim svojim radostima, nadama i problemima. $\ll{ }^{11} \mathrm{Na}$ povijesnom putu rasta i sazrijevanja obitelj prati »stalni poziv koji dolazi iz punog

\footnotetext{
${ }^{6}$ Isto.

${ }^{7}$ Isto, br. 77.

${ }^{8}$ Isto.

${ }^{9}$ Usp. isto, br. 325.

${ }^{10}$ Isto.

${ }^{11}$ Isto, br. 57.
} 
zajedništva Presvetog Trojstva, iz divnog jedinstva između Krista i njegove Crkve, iz one lijepe zajednice koja je sveta nazaretska obitelj kao i iz čistoga bratstva koje postoji među svetima na nebu $\ll^{12}$.

Obitelj nije dakle bez uzora, bez podrške i pomoći na putu prema svojoj eshatološkoj punini. Na tom putu, dakako, svoju važnu ulogu ima sakrament ženidbe kao $\gg$ dar za posvećenje i spasenje supruga $\ll^{13}$. »Brak je 'dar' Gospodnji $\ll$ (usp. 1 Kor $7,7)^{14}$, on je istodobno zvanje ${ }^{15} \mathrm{i} \gg$ dragocjeni znak $\ll{ }^{16}$ koji podsjeća i upućuje na jedinstvo i ljubav između Krista i Crkve. Sakrament ženidbe, kao i svaki drugi dar Gospodnji u službi je Božjega kraljevstva, u službi novih odnosa između Boga i ljudi, u službi bezuvjetne i neopozive Božje ljubavi i vjernosti koja se očitovala u žrtvi Kristova križa.

\section{2. Čovjekova bogolikost - temelj naravne ženidbe}

Naravna ženidba svoje temeljno uporište ima u čovjekovoj stvorenosti na sliku i priliku Božju. Svaki čovjek, pod time dakako mislimo na muškarca i ženu kao individue, pojedince, slika je i prilika Božja (usp. Post 1,26), a posinodalna pobudnica o ljubavi u obitelji Amoris laetitia, na temelju retka Post 1, 27, to svojstvo posebno ističe i primjenjuje na ljudski par: »Na svoju sliku stvori Bog čovjeka, na sliku Božju on ga stvori, muško i žensko stvori ih.« Tu se dakle izraz slika Božja dovodi u izravnu vezu s parom $\gg$ muško i žensko $\ll{ }^{17}$. Takvu tvrdnju kojom se izriče temeljna stvarnost ljudskoga para pobudnica promatra kao »iznenađujuću činjenicu $\ll^{18}$. Dakle, kao što je svaki čovjek kao pojedinac (individua) slika Božja, tako je također slika Božja i svaki ljudski »muško i ženski« par (bračna zajednica).

Dok naglašava Božju transcendentnost i odlučno odbacuje kanaanski kult plodnosti, kao i predodžbe o Bogu kao spolnom biću koje bi eventualno utjecalo na razumijevanje čovjeka kao slike Božje, pobudnica u plodnosti ljudskoga para vidi živu i djelotvornu $\gg$ sliku «, vidljivi znak Božjega stvaralačkoga čina: »Bračni par koji voli i rađa život pravi je i živi 'kip' (ne od kamena ili zlata zabranjenih Dekalogom), ka-

\footnotetext{
${ }^{12}$ Isto, br. 325 .

${ }^{13}$ Isto, br. 72 .

${ }^{14}$ Isto, br. 61.

${ }^{15}$ Usp. isto, br. 72 .

${ }^{16}$ Isto, br. 121.

${ }^{17}$ Usp. isto, br. 10.

${ }^{18}$ Isto.
} 
dar očitovati Boga stvoritelja i spasitelja. $\ll{ }^{19}$ Drugim riječima, bračni par povlašteno je mjesto Božje dobrohotne i djelatne, stvaralačke i životvorne prisutnosti. Božje stvaranje nastavlja se u uzajamnoj i plodnoj ljubavi muškarca i žene: »Rađanje i odgoj djece odraz je Očeva djela stvaranja. $\ll{ }^{20}$

Čovjek dakle svoju bogolikost ostvaruje ne samo rađanjem nego i odgajanjem djece. Kao što je Bogu Stvoritelju sličan rađajući djecu, tako mu je sličan i po odgajanju djece, po njegovanju i brizi za njih. Rađanje i odgoj djece intimno su povezani i uvijek idu zajedno. Kao što Stvoritelj svojom ljubavlju nastavlja pratiti svoje stvorenje koje je pozvao u život, nastavlja mu se otkrivati i darivati, odgaja ga i usmjerava, tako je i čovjek pozvan ljubavlju i nježnošću pratiti rast svoje djece, odgajati ih i usmjeravati. Prema tomu, u rađanju i odgajanju djece u čovjeku se odražavaju i zrcale i crte Boga koji stvara i crte Boga koji spašava. Po mogućnostima i sposobnostima rađanja i odgajanja koje je primio od svoga Stvoritelja čovjek ima udjela na Božjem djelu stvaranja i spasenja.

U životno zajedništvo i plodnost muškarca i žene položeni su također temelji na kojima raste i razvija se povijest spasenja: $\gg$ Sposobnost ljudskog para da rađa put je po kojem se povijest spasenja razvija. $\ll{ }^{21} \mathrm{U}$ tom svjetlu treba čitati i razna rodoslovlja u kojima se potvrđuje čvrsta sveza poretka stvaranja s poretkom spasenja. U povijesti pojedinoga roda, odnosno obitelji objavljuje se povijest Božje konkretne ljubavi i vjernosti prema ljudima. Bog svoj naum spasenja ne izvodi po savršenim ljudima, ne služi se savršenim parom muškarca i žene. Njegov izbor osoba i načina djelovanja redovito iznenađuje ljudska očekivanja: »Jer misli vaše nisu moje misli i puti moji nisu vaši puti.« (Iz 55, 8) Unatoč nevjernosti naroda koja je u proroka često opisana slikom preljuba, nevjerom zaručnice, odnosno žene prema svomu zaručniku, odnosno mužu, Bog ostaje vjeran (usp. Ez 16; Hoš 2). Povijest njegova odnosa s ljudima može se nastaviti samo zahvaljujući njegovu milosrđu, tomu što on uvijek ostaje vjeran (usp. Iz 34, 6; Pnz 32, 4; 2 Tim 2, 13).

Nadalje, u plodnosti ljudskoga para ne pokazuju se samo crte Boga koji stvara život, nego ta ista plodnost za pobudnicu postaje slikom za »razumijevanje i opisivanje

\footnotetext{
${ }^{19}$ Isto, br. 11. Usp. I. GOLUB, Prijatelj Božji, Zagreb, 1990., str. 97.: »Izraz 'Slika Božja' na Orijentu, posebno semitskom, znači da u onom što se naziva slikom Božjom - to može biti likovni ili nelikovni kip, slika - jest prisutno sámo božanstvo, odnosno božanski fluid. Izrazom dakle da je čovjek stvoren na Božju sliku prvenstveno je izraženo da je čovjek što ga je Bog stvorio na neki način Božje prebivalište, da je Bog u njemu nekako prisutan. Iz toga slijedi da je prva obitelj što ju je Bog stvorio, a u koju je nekako uključena cijela obitelj ljudskog roda, bila stvorena kao slika Božja, tj. kao biće u kojem je Bog prisutan.«

${ }^{20}$ AL, br. 29.

${ }^{21}$ Isto, br. 11.
} 
otajstva samog Boga $\ll^{22}$, svojevrsni ključ pomoću kojega možemo $\gg$ zaviriti $\ll u$ Božju unutrašnjost, u otajstvo Presvetoga Trojstva, u zajedništvo Oca, Sina i Duha Svetoga. Naime, kad je Bog čovjeka učinio svojom slikom, dao mu je neku vrstu ključa ne samo za poznavanje sebe (čovjeka) nego i za poznavanje njega samoga (Boga). ${ }^{23}$ Obitelj, kao životna zajednica ljubavi muža, žene i djeteta, ploda njihove ljubavi, životni je odraz Trojstvenoga Boga, zajednice ljubavi. Pobudnica, kada govori o toj »teofanijskoj《 ulozi i značenju obitelji, poziva se na riječi Ivana Pavla II.: »Naš Bog, u svojem najdubljem otajstvu, nije samoća, već obitelj, jer u sebi ima očinstvo, sinovstvo i bit obitelji koja je ljubav. Ta ljubav u božanskoj obitelji, jest Duh Sveti. ${ }^{24}$ Obitelj na neki način pripada samoj Božjoj biti. ${ }^{25}$

U pobudnici se, među ostalim, kaže kako nam Sveto pismo i predaja otvaraju pristup spoznaji Trojstva koje se objavljuje s obiteljskim crtama. »Obitelj je tako slika Boga koji (...) je zajedništvo osoba. ${ }^{26}$ Mogli bismo čak izravnije reći, obitelj je slika Božja, tj. mjesto Božje trojstvene prisutnosti, prostor njegove djelatne i spasonosne ljubavi. Naime, prema apostolskoj pobudnici, obitelj je »povjerena muškarcu, ženi i djeci da tvore zajednicu osoba koja će biti slika jedinstva između Oca, Sina i Duha Svetoga $\ll{ }^{27}$. Obitelj tako ima dvostruko poslanje, s jedne strane ona podsjeća i upućuje na otajstvo Trojedinoga Boga, na Otajstvo ljubavi iz kojega sve proizlazi, a s druge strane život u zajedništvu Trojedinoga Boga uzor je i mjera obiteljskoga života, stvarnost kojoj se obitelj sve više i potpunije treba upriličiti. Obitelj je zajednica ljubavi u kojoj se treba moći spoznati i doživjeti tko je i kakav je Bog.

Dakako, govor o otajstvu Trojedinoga Boga moguć je tek u svjetlu novozavjetne objave, u svjetlu Kristova događaja. Tek nakon što nam se Isus Krist objavio kao Očev Sin, odnosno nakon što nam je Otac u Isusu Kristu objavio svoga ljubljenoga Sina, i nakon što nam je Sin od Oca poslao Duha, Ljubav Oca i Sina, možemo govoriti o Presvetom Trojstvu. Otada možemo u sebi, odnosno u obitelji slutiti i prepoznati crte Božjega trojstvenoga života; na temelju svoje komunitarne, »obiteljske«

\footnotetext{
${ }^{22}$ Isto.

${ }^{23}$ Usp. I. GOLUB, Prijatelj Božji, 145-146. Prema Golubu svaki čovjek kao slika Božja svojom vremenitošću, svojim razvojem i rastom neprestano otkriva Boga: »Pruža, da tako reknem, živu sliku o Bogu, rastuću sliku (...). Budući da je čovjek živa i rastuća slika Božja, spoznaja o Bogu je u neprestanom rastu i u novoj životnosti.« (Isto, 145.)

${ }^{24}$ AL, br. 11.

${ }^{25}$ Pobudnica se poziva na homiliju Ivana Pavla II. u Puebli de los Ángelesu (28. siječnja 1979.), 2. : AAS 71(1979.), 184.

${ }^{26}$ AL, br. 71.

${ }^{27}$ Isto, br. 29.
} 
naravi možemo razmišljati o svojevrsnoj pluralnosti u Bogu, o Božjem komunitarnom biću, o njegovoj »obiteljskoj « biti.

No i dok nam otajstvo Trojedinoga Boga nije objavljeno u Isusu Kristu, u otajstvima njegova utjelovljenja, života, muke, smrti i uskrsnuća, ono je od početka, u samom stvaranju upisano u čovjeka, ako je čovjek po svojoj naravi bitno relacijsko biće, osoba u odnosu prema drugoj osobi, osoba koja sebe duguje ljubavi drugih osoba. Drugim riječima, biti stvoren na sliku Božju znači biti stvoren na sliku Trojedinoga Boga, a što dalje opet znači biti stvoren za život u zajednici osoba, u braku, odnosno u obitelji. Kako je svaki čovjek stvoren na sliku i priliku Božju te je tako bitno određen bliskim i prijateljskim odnosom s Bogom, tako je i svaka naravna ženidba, životni i plodni odnos ljubavi muškarca i žene također u bliskom i životnom odnosu s Bogom, stvarnost na sliku i priliku Božju. I ona je također mjesto Božje djelatne prisutnosti, »prostor $\ll$ njegove objave.

U međusubnom darivanju, u ljubavi i plodnosti muškarca i žene, u sposobnosti bračnoga para da $\gg$ voli i rađa život $\ll^{28}$ objavljuje se i ostvaruje čovjekova bogolikost, Božja životodajna i komunitarna, stvoriteljska i spasiteljska prisutnost. U svakom bračnom paru postoji dakle svojevrsna, nazovimo je naravna, temeljna sakramentalnost, početna, temeljna milost, jer biti stvoren, stvoren na sliku i priliku Božju, postojati kao muškarac i žena, moći živjeti u bračnom zajedništvu, rađati i odgajati djecu, to je jednostavno temeljni i osnovni dar ili milost, ono što nitko ne može sebi dati, nego može samo primiti, ustvrditi da mu je to darovano, vlastito njegovu načinu postojanja koji sâm nije izmislio, već je to kao stvorenje primio.

\section{Kristovo otajstvo spasenja - osnova za razumijevanje sakramentalnosti ženidbe}

Kada govorimo o sakramentalnoj ženidbi, onda odmah imamo pred očima s jedne strane otajstvo grijeha (mysterium iniquitatis), odnosno palu i ranjenu ljudsku narav, grijehom oštećenu i zasjenjenu čovjekovu bogolikost, a s druge strane djelo otkupljenja i dovršenja koje se upravo u vidu obnove čovjekove bogolikosti dogodilo u Isusu Kristu, slici Božjoj (usp. 2 Kor 4, 4; Kol 1, 15), Prvorođencu svakoga stvorenja (usp. Kol 1, 15). Sve je u njemu, »po njemu i za njega stvoreno « (Kol 1, 16). U njemu naime $\gg$ tjelesno prebiva sva punina božanstva « $(\mathrm{Kol} \mathrm{2}, 9)$.

Grijehom je bračni par poremetio prvotni sklad kakav je u izvornom Božjem promislu trebao vladati između muškarca i žene. U bračno zajedništvo u kojem je ponestalo bliske i prijateljske Božje prisutnosti uvuklo se međusobno otuđenje, odnos ljubavi i čistoće između muškarca i žene preobrazio se u žudnju i gospodarenje. ${ }^{29} \mathrm{U}$

\footnotetext{
${ }^{28}$ Isto, br. 11.

${ }^{29}$ Usp. AL, br. 19.
} 
iskustvo bračnoga života ušla je patnja, zlo, nasilje, »koji razdiru život obitelji i njezino duboko zajedništvo života i ljubavi $\ll^{30}$.

Iz takvoga stanja grijeha bračni par ne može izići svojim snagama, sâm se ne može vratiti u prvotno zajedništvo s Bogom od kojega se svojom voljom odmetnuo (usp. Post 3), a u kojem je u svijetu bio živi i vidljivi odraz Božjega otajstva. Ako pokaže želju, u to ga zajedništvo može ponovno vratiti samo onaj od koga se neposlušnošću i ohološću odijelio, tj. sâm Stvoritelj. Tu započinje govor o spasenju, odnosno o otkupljenju. Ono se dogodilo u Isusu Kristu, po kome i za koga je sve stvoreno (usp. Kol 1, 16). Krist je dakle, kako naglašava apostolska pobudnica, otkupio obitelj i ženidbu (usp. Ef 5, 21-32), obnovio ih »na sliku Presvetog Trojstva, otajstva iz kojeg izvire svaka prava ljubav ${ }^{31}$. Na taj način, kako se na drugome mjestu kaže i dijelom ponavlja: »Ljudskoj obitelji, koju Krist okuplja oko sebe, vraćena je (...) slika i prilika Presvetog Trojstva (usp. Post 1,26), otajstva iz kojega izvire svaka prava ljubav. $\ll^{32}$

Drugim riječima, po otkupljenju i obnovi obitelji i ženidbe, toga temeljnoga zajedništva života i ljubavi, Krist oko sebe okuplja, otkupljuje i obnavlja cijelu ljudsku obitelj. Naime, kako se kaže i u pobudnici: »Ženidba i obitelj primaju od Krista, po Crkvi, nužnu milost za svjedočenje Božje ljubavi i življenje zajedništva. ${ }^{33}$ Stoga se može reći kako je milost ljubavi i zajedništva kojom se hrani ženidba i obitelj usmjerena i namijenjena također široj obitelji. Naime veliku obitelj čovječanstva Krist obnavlja po Crkvi, koja je u njemu »na neki način sakrament odnosno znak i sredstvo najprisnijeg sjedinjenja s Bogom i jedinstva cijeloga ljudskog roda $\ll^{34}$. $\mathrm{U}$ tom pogledu Isus, koji je u sebi sve pomirio i čovjeka otkupio od grijeha, »nije tek vratio ženidbu i obitelj u izvorno stanje, nego je uzdigao brak na razinu sakramentalnog

\footnotetext{
${ }^{30}$ Isto, br. 19.

${ }^{31}$ Isto, br. 63 .

${ }^{32}$ Isto, br. 71. Odnos između stvaranja i otkupljenja u pogledu bračne ljubavi objašnjen je u pastoralnoj konstituciji o Crkvi u suvremenom svijetu Gaudium et spes u broju 49, i to trima glagolima: iscijeliti (sanare), usavršiti (perficere) i uzdignuti (elevare). Riječ je o trima tradicionalnim terminima koji međutim u koncilskom kontekstu poprimaju posebno značenje. Glagol »iscijeliti « znači da Krist oslobađa od »tvrdoće srca « koja priječi živjeti vjernost Savezu. »Usavršiti« znači da ljudska ljubav, oslobođena grijeha, u potpunosti može ostvariti Božji naum. Na kraju, »uzdignuti « ne znači da jedna stvarnost postaje moralnom, koja to inače nije, nego da se stvarnost ljudske ljubavi sa svojim ucjepljenjem u Božju ljubav, po sakramentu krštenja, preobražava. Usp. M. ALIOTTA, Il Matrimonio, Brescia, 2002., 94.

${ }^{33}$ AL, br. 71.

${ }^{34}$ DRUGI VATIKANSKI KONCIL, Lumen gentium. Dogmatska konstitucija o Crkvi (21. XI. 1964.), br. 1, u: ISTI, Dokumenti, Zagreb, ${ }^{72008 . ~(=~ L G) . ~}$
} 
znaka njegove ljubavi prema Crkvi (usp. Mt 19, 1-12; Mk 10, 1-12; Ef 5, 21-32) «35. Pripadajući jedno drugomu, supruzi $\gg$ sakramentalnim znakom, uprisutnjuju odnos Krista s njegovom Crkvom $\ll^{36}$.

Ženidba i obitelj imaju dakle svoje sakramentalno značenje i ulogu. Povezano s time, one imaju također i svoje misijsko, odnosno evangelizatorsko poslanje i prema samoj Crkvi i prema svijetu. Na intimnu povezanost i sličnost uže i šire obitelji upućuje i sljedeća misao: »U hramu bračnog zajedništva je prisutno Trojstvo. Kao što ono prebiva u hvali svoga naroda (usp. Ps 22, 4), 'tako živi duboko unutar bračne ljubavi koja mu daje slavu. $\ll{ }^{37} \mathrm{U}$ tim riječima mogu se već prepoznati eklezijalne dimenzije braka i obitelji, onoga što će crkvena starina, a u naše vrijeme Drugi vatikanski koncil i na njegovu tragu suvremeno crkveno učiteljstvo, uključivši aktualno, označiti kao kućnu Crkvu (ecclesia domestica). ${ }^{38}$ Ženidba i brak mjesto su duhovnoga bogoslužja. Životni prostor neke obitelji u novozavjetnim zajednicama služio je kao kućna crkva, sjedište euharistije, »prisutnosti Krista koji sjedi za istim stolom $\ll^{39}$.

Pozivajući se na nauk o braku i obitelji iznesen na Drugom vatikanskom koncilu u pastoralnoj konstituciji Gaudium et spes ${ }^{40}$ o odnosu, značenju i ulozi ženidbe i obitelji prema Crkvi, među ostalim, kaže se kako Krist Gospodin u utjelovljenju »preuzima na sebe ljudsku ljubav, čisti je, privodi punini i, svojim Duhom, daje ženidbenim drugovima sposobnost da je žive, prožimajući sav njihov život vjere, nade i ljubavi $\ll^{41}$. Naime po sakramentu ženidbe Krist dolazi ususret kršćanskim supruzima i s njima ostaje. On ih svojom trajnom prisutnošću posvećuje te čini sposobnima da $\gg$ po sebi svojstvenoj milosti, izgrađuju Tijelo Kristovo i čine kućnu Crkvu (usp. LG 11) ${ }^{42}$. Kako bi shvatila Kristovo otajstvo, Crkva, kaže se u pobudnici, svoj pogled upravlja »na kršćansku obitelj, koja to očituje na istinski

\footnotetext{
${ }^{35}$ AL, br. 71.

${ }^{36}$ Isto, br. 72 .

${ }^{37}$ Isto, br. 314.

${ }^{38}$ Usp. LG, br. 11; DRUGI VATIKANSKI KONCIL, Apostolicam actuositatem. Dekret o apostolatu laika (18. XI. 1965.), br. 11, u: ISTI, Dokumenti, Zagreb, ${ }^{72008}$. Opširnije o povijesti i teologiji domaće Crkve u: E. CASTELLUCCI, La Chiesa domestica dai padri al Vaticano II, u: R. FABRIS, ISTI (ur.), Chiesa domestica. La Chiesa - famiglia nella dinamica della missione italiana, Bologna, 2009., 129-214.

${ }^{39}$ AL, br. 15.

${ }^{40}$ Usp. DRUGI VATIKANSKI KONCIL, Gaudium et spes. Pastoralna konstitucija o Crkvi u suvremenom svijetu (7. XII. 1965.), br. 47-52, u: ISTI, Dokumenti, Zagreb, ${ }^{72008 . ~(=~ G S) . ~}$

${ }^{41}$ AL, br. 67.

${ }^{42}$ Isto.
} 
način « ${ }^{43}$. Drugim riječima, obitelj kao kućna Crkva, Crkva u malom, predstavlja za Crkvu model i uzor kako se svakodnevno i konkretno živi otajstvo Kristova spasenja, otajstvo njegove žrtve i ljubavi.

Pobudnica naime naglašava snažnu ukorijenjenost ženidbenih drugova u Kristu, a ona seže u sakrament krštenja. Izričito se kaže: »Uzajamno darivanje, koje je sastavni dio sakramentalne ženidbe, ima svoje korijene u milosti krštenja, koja uspostavlja temeljni savez svake osobe s Kristom u Crkvi. $\ll{ }^{44}$ Već je spomenuto kako je život bračnih drugova posvećen trajnom Kristovom prisutnošću. Krist podržava i hrani njihovu uzajamnu ljubav svojim Duhom kako bi u cjelovitom predanju jedno drugom mogli ostvariti svetost na koju su zajedno pozvani. ${ }^{45}$ Uzajamno darivanje jedini je put koji ženidbene drugove vodi do svetosti. $\mathrm{U}$ tom pogledu $\mathrm{i} \gg$ spolno združivanje, življeno s ljubavlju i posvećeno sakramentom, za ženidbene je drugove put rasta u milosnom životu $\ll^{46}$. Takvo združivanje pobudnica izričito označava kao $\gg$ bračno otajstvo $\ll{ }^{47}$.

U pobudnici se stoga i naglašava kako $\gg$ sakrament ženidbe nije društveni ugovor, prazni ritual ili samo vanjski znak opredijeljenosti. Sakrament je dar za posvećenje i spasenje supruga $\ll^{48}$. Krist, kako je već rečeno, po sakramentu ženidbe dolazi ususret kršćanskim supruzima i s njima ostaje kako bi ga mogli slijediti »uzimajući na se svoj križ, da se nakon padova ponovno dižu, da si uzajamno opraštaju, da nose terete jedno drugoga $\ll{ }^{49}$.

Sakrament ženidbe jest dakle Gospodnji dar supružnicima, no on je istodobno i dragocjeni znak, jer »kad muškarac i žena slave sakrament ženidbe, Bog, tako reći, 'odražava' se u njima, utiskuje u njih svoje crte i neizbrisivi biljeg svoje ljubavi. Brač-

${ }^{43}$ Isto.

${ }^{44}$ Isto, br. 73.

${ }^{45}$ Usp. AL, br. 69. Usp. LG, br. 41, gdje se u sklopu V. poglavlja: Opći poziv na svetost u Crkvi, o kršćanskim supružnicima kaže: »Kršćanski se ženidbeni drugovi i roditelji, slijedeći vlastiti put u vjernoj ljubavi, moraju tijekom cijeloga života uzajamno podržavati u milosti te kršćanskim naukom i evanđeoskim krjepostima prožeti potomstvo koje su s ljubavlju od Boga primili. Tako oni, naime, svima pružaju primjer neumorne i velikodušne ljubavi, izgrađuju bratstvo ljubavi te postaju svjedocima i suradnicima plodnosti Majke Crkve, za znak i udioništvo u onoj ljubavi kojom je Krist ljubio svoju Zaručnicu te sama sebe za nju predao.«

${ }^{46}$ AL, br. 74.

${ }^{47}$ Isto. Usp. GS, br. 48, gdje se u govoru o svetosti ženidbe i obitelji, među ostalim, kaže kako muž i žena, koji po ženidbenom savezu »više nisu dva, nego jedno tijelo « (Mt 19,6), »intimnim sjedinjenjem osobâ i djelâ pružaju uzajamnu pomoć i službu te iskusuju smisao svojega jedinstva i iz dana u dan ga sve potpunije stječu « .

${ }^{48}$ AL, br. 72.

${ }^{49}$ Isto, br. 73. Usp. KATEKIZAM KATOLIČKE CRKVE, Zagreb, 1994., br. 1642 (= KKC). 
na je zajednica slika ljubavi Božje prema nama. Bog je, naime također zajedništvo: tri osobe, Otac, Sin i Duh Sveti, žive oduvijek i zauvijek u savršenom jedinstvu. I to je upravo otajstvo ženidbe: Bog čini od supruga jedan život $\ll^{50}$. Dakle sakrament ženidbe jest »dragocjeni znak « ne samo u kristološko-ekleziološkom pogledu, po tome što je Krist uzdigao brak na razinu sakramentalnoga znaka njegove ljubavi prema $\mathrm{Crkvi}^{51}$, nego i po svojoj trojstvenoj dimenziji, ako se u bračnoj zajednici odražava ljubav i savršeno jedinstvo Presvetoga Trojstva.

A kada je o kristološkoj dimenziji braka riječ, pobudnica još ističe kako je kršćanska ženidba znak koji »ne samo pokazuje koliko je Krist ljubio svoju Crkvu u savezu zapečaćenom na križu nego također uprisutnjuje tu ljubav u zajedništvu supruga. Združujući se u jedno tijelo, oni predstavljaju sjedinjenje Sina Božjega s ljudskom naravi ${ }^{52}$. Tu se još jasnije vidi koliko je u sakramentu ženidbe tijesno povezano otajstvo Trojedinoga Boga s otajstvom utjelovljenja Sina Božjega.

Treba još reći, uz to što je sakramentalna ženidba Gospodnji dar i dragocjeni znak, ona je, što je također već naznačeno, i zvanje, odnosno poslanje: »Brak je zvanje, budući da je odgovor na određeni poziv na življenje bračne ljubavi kao nesavršenog znaka ljubavi između Krista i Crkve. $\ll^{53} \mathrm{U}$ pobudnici se dalje kaže kako »ženidba i obitelj primaju od Krista, po Crkvi, milost Duha Svetoga da svjedoče evanđelje Božje ljubavi $\ll^{54}$. Navodeći apostolsku pobudnicu Ivana Pavla II. Familiaris consortio ${ }^{55}$, još se u tom istom kontekstu ističe kako su bračni drugovi za Crkvu »trajan podsjećaj onoga što se zbilo na križu $\ll^{56}$ : »Oni su jedan za drugoga i za svoju djecu živi svjedoci spasenja kojega ih sakrament čini dionicima. ${ }^{57}$

Na kraju ovoga dijela važno je napomenuti kako je bračna ljubav, ipak, »nesavršeni znak ljubavi između Krista i Crkve $\ll^{58}$, a tako i nesavršeni odraz ljubavi i jedinstva u zajedništvu Presvetoga Trojstva pa u tom pogledu pobudnica s pravom upozorava na potrebu »sakramentalnog realizma «: »Ne smije se na dvije ograničene osobe svaljivati golemo breme da moraju savršeno reproducirati jedinstvo koje postoji između Krista i njegove Crkve, jer brak kao znak uključuje

\footnotetext{
${ }^{50}$ AL, br. 121.

${ }^{51}$ Usp. isto, br. $71,72$.

${ }^{52}$ Isto, br. 73 .

${ }^{53}$ Isto, br. 72 .

${ }^{54}$ Isto, br. 73.

${ }^{55}$ FC, br. 13.

${ }^{56} \mathrm{AL}$, br. 72 .

${ }^{57}$ Isto.

${ }^{58}$ Isto.
} 
'dinamičan proces koji postupno vodi naprijed, zahvaljujući rastućem ujedinjavanju Božjih darova. $\ll{ }^{59}$ Drugim riječima, samo je Isus Krist savršena i potpuna slika Božja (usp. 2 Kor 4, 4; Kol 1, 15; 2, 9), »odsjaj slave i otisak Bića njegova « (Heb 1, 3), a čovjek pojedinac odnosno bračni par nesavršena je, dinamična i rastuća slika Božja (usp. 2 Kor 3, 18). Naime i oni koji su kršteni i imaju prvine Duha u sebi uzdišu $\gg$ iščekujući posinstvo, otkupljenje svoga tijela« (Rim 8, 23). $\gg$ U nadi su spašeni! « (Rim 8,24) Naime evanđelje obitelji, kako je već u uvodu spomenuto, svoju će puninu doseći tek tada kada se ispuni otajstvo saveza u Kristu $\gg$ na kraju svijeta sa svadbom Jaganjčevom « (usp. Otk 19, 9) ${ }^{60}$.

\section{4. (Su)odnos između naravne i sakramentalne ženidbe}

Prema pobudnici Amoris laetitia čini se da (su)odnos između naravne i sakramentalne ženidbe najbolje dolazi do izražaja u činjenici što su u tradiciji zapadne Crkve »djelitelji sakramenata ženidbe muškarac i žena koji se žene, koji, pokazuju svoj uzajamni pristanak i izražavajući ga u uzajamnome tjelesnom darivanju, primaju veliki dar $\ll^{61}$. U pobudnici se dalje kaže kako su njihov pristanak i njihovo tjelesno sjedinjenje sredstva pomoću kojih ih Bog čini $\gg$ jednim tijelom $\ll$. $\gg$ Po svojemu krsnom posvećenju oni su osposobljeni sjediniti se u braku kao Gospodinovi služitelji i na taj način odgovoriti na Božji poziv. $\ll^{62}$

Treba podsjetiti kako ni u jednom drugom sakramentu svjetovno djelo i znak vjere nisu toliko međusobno isprepleteni. Krštenje je temeljni razlikovni znak (kriterij) po kojem se naravna ženidba razlikuje od sakramentalne ženidbe, pa se zato u pobudnici kaže: »Prema tome, kada dvoje supruga koji nisu kršćani prime krštenje, nije potrebno da obnavljaju bračne zavjete; dovoljno je da ih ne odbacuju, jer po primljenom krštenju njihovo zajedništvo postaje sakramentalno. $\ll^{63}$ Crkvena ženidba dvoje kršćana zapravo je posveta naravne sakramentalnosti »po kojoj naravna bračna veza, odnosno građanski brak, postaje dodatno oplemenjen Božjom milošću. Prirodna ljubav zaodijeva se u božansku da bi uistinu postala ono što jest. ${ }^{64}$ Prirodni je poredak dakle toliko prožet otkupiteljskom milošću Isusa Krista da »među krštenima ne može biti valjanog ženidbenog ugovora koji samim tim ne

\footnotetext{
${ }^{59}$ Isto, br. 122.

${ }^{60}$ Isto, br. 63.

${ }^{61}$ Isto, br. 75 .

${ }^{62}$ Isto.

${ }^{63}$ Isto.

${ }^{64}$ Đ. HRANIĆ, Ženidba: prirodni poredak prožet otkupiteljskom milošću, u: Vjesnik Đakovačkoosječke nadbiskupije i Srijemske biskupije 145( 2017.)1, 3.
} 
bi bio i sakrament $\ll^{65}$. Tom je tvrdnjom još jednom istaknuto središnje mjesto $\mathrm{i}$ značenje Isusa Krista i u djelu stvaranja i u djelu otkupljenja, »sve je po njemu i za njega stvoreno « $(\mathrm{Kol} 1,16)$. Ta dva poretka u njemu su savršeno povezana, a na tu čvrstu povezanost upravo najbolje upozorava sakrament ženidbe u kojem se naravna ženidba kao slika Božja, grijehom ranjena i narušena, obnavlja i upriličuje Kristu, savršenoj slici Božjoj.

Više od svih drugih sakramenata, kako ističe Franz-Josef Nocke, »ženidba svjedoči o utjeloviteljskoj strukturi milosti, o jedinstvu ljubavi prema Bogu i bližnjemu $\ll{ }^{66}$. Za one koji vide tu vezu ženidba je znak Božje blizine: »bračno zajedništvo pruža iskustvo fascinirajućeg i potresnog Božjeg otajstva, pouzdanje u Boga daje braku svoju dubinu i čvrstoću. $\ll{ }^{67}$ Liturgijsko slavlje vjenčanja upravo je izraz toga: ono je znak vjere u Boga koji je izvor i obzor ljubavi. Kršćansko uvjerenje kako je tamo gdje se stvarno ljubi i sam Bog na djelu odnosi se na sve ljude. Međutim oni koji ne dijele tu vjeru ne će pripisati ženidbi to simbolično značenje. Katolička teologija brine se o toj činjenici tako što priznaje javno sklopljene brakove nekrštenih osoba valjanima, ali ih ne naziva sakramentom. ${ }^{68}$ Dakle razlika između sakramentalne i nesakramentalne (naravne) ženidbe nije identična ženidbi sklopljenoj u crkvi i onoj sklopljenoj izvan crkve. Glavni kriterij jest krštenje, krštenje kao sakrament vjere. Stoga se i ženidbe osoba krštenih izvan Katoličke Crkve nazivaju sakramentom, i to neovisno od slavlja vjenčanja u crkvi.

Katolička Crkva $\gg$ za svoje vjernike redovito traži crkveni oblik vjenčanja $\ll^{69}$. Za nju je sakramentalno sklapanje ženidbe liturgijski čin, pa ju je prema tomu prikladno slaviti $\mathrm{u} \gg$ javnom crkvenom bogoslužju $\ll^{70}$. Možda je tu potrebno podsjetiti kako kolokvijalni izraz »vjenčati se u crkvi « uključuje šire i dublje značenje od samoga materijalnoga prostora (zgrade), on naime u prvom redu podrazumijeva ženidbu kao crkvenu stvarnost, a Crkvu kao živi i sveti Hram Božji u kojemu prebiva Duh

\footnotetext{
${ }^{65} \mathrm{AL}$, br. 75.

${ }^{66}$ F.-J. NOCKE, Ehe, u: Handbuch der Dogmatik, II, Düsseldorf, 1992., str. 374.

${ }^{67}$ Isto.

${ }^{68}$ Usp. isto.

${ }^{69}$ KKC, br. 1631. Katekizam Katoličke Crkve tu upućuje na dekret Tridentskoga koncila Tametsi (DH, br. 1813-1816), gdje se propisuje sklapanje ženidbe »pred licem Crkve « (in facie Ecclesiae) (DH, br. 1814), te na Zakonik kanonskoga prava (1983.), kan. 1108. koji kaže kako su valjane »samo one ženidbe koje se sklapaju u prisutnosti mjesnog ordinarija ili župnika, ili svećenika ili đakona koje ovlasti jedan od njih dvojice, a i dvojice svjedoka (...).« U kan. 1063. istoga Zakonika govori se o tome kako su pastiri duša obvezni brinuti se $\gg$ da vlastita crkvena zajednica pruža vjernicima pomoć kojom se ženidbeni stalež održava u kršćanskom duhu i napreduje u savršenosti«. Ta se pomoć, među ostalim, treba pružiti »plodonosnim bogoslužnim slavljenjem ženidbe kojim neka se pokaže da ženidbeni drugovi očituju otajstvo jedinstva i plodne ljubavi između Krista i Crkve i da imaju udjela u njemu «.

${ }^{70} \mathrm{KKC}$, br. 1631.
} 
Božji (usp. 1 Kor 3, 16), pa slavlje sakramenta ženidbe $\gg$ u Crkvi « znači ulazak u intimnu zajednicu bračnoga života i bračne ljubavi, slavlje koje se događa u zajednici vjere, u zajedništvu Kristovih vjernika, u Crkvi - otajstvenom Tijelu kojemu je Krist Glava. U tom smislu ženiti se $\gg$ u Crkvi « i ženiti se $\gg$ u Gospodinu $\ll(1$ Kor 7,39$)$ moglo bi imati slično, gotovo isto značenje: sjedinjenje s Gospodinom ostvaruje se u zajednici vjere i ljubavi, u zajednici koja je Hram Božji, svet, u kojoj prebiva Duh Božji. Gospodin naime nikada nije bez Crkve, svoga Tijela, kao što ni Crkva nikad nije bez Gospodina, svoje Glave. Takvim razumijevanjem »ženidbe u Crkvi « lakše je razumjeti i samu sakramentalnost ženidbe, tj. uprisutnjeno i djelatno jedinstvo i ljubav Krista i Crkve u bračnoj zajednici muža i žene. Na taj se način pokazuje duboka povezanost između otajstva Crkve i otajstva ženidbe. Ženidba, među ostalim, »uvodi u određeni crkveni stalež, u Crkvi uspostavlja među supružnicima kao i prema djeci stanovita prava i dužnosti $\ll^{71}$.

U pogledu odnosa između naravne i sakramentalne ženidbe može se primijeniti općenito načelo po kojem milost ne poništava narav, nego je pretpostavlja i usavršava: Gratia supponit naturam et perficit eam. Svaki čovjek kao Božje stvorenje ujedno je i slika Božja; svaki je čovjek nakon grijeha praroditelja po rođenju baštinio oštećenu sliku Božju, ali ne i uništenu, jer i dalje ostaje stvorenje koje svoje zadovoljstvo i ispunjenje jedino može naći u Bogu; on je i dalje osoba koju Bog želi i traži, osoba koju je Bog $\gg \mathrm{u}$ punini vremena « našao $\mathrm{u} \gg$ novom Adamu $\ll$, $\mathrm{u}$ Isusu Kristu. Isus Krist je naime po otajstvu svoje poslušnosti obnovio i spasio čovjeka - sliku Božju, vratio ga u puno zajedništvo $\mathrm{s}$ Trojedinim Bogom. $\mathrm{U}$ njemu naime $\gg$ tjelesno prebiva sva punina božanstva « $(K o l 2,9)$. Prema novozavjetnoj teologiji, on je, zapravo, jedina prava i potpuna »slika Božja « $(2$ Kor 4, 4). Svaki je čovjek stoga upućen na Isusa Krista, jer se slika Božja u »palom čovjeku « isključivo obnavlja i spašava u slici i po slici Kristovoj.

Krist je jedina mjera čovjekove bogolikosti, isključivo »mjesto «, odnosno osoba čovjekova bliskoga i prijateljskoga susreta s Bogom. Kristovo djelo spasenja namijenjeno je stoga svim ljudima. Bog naime želi da se svi ljudi spase (1 Tim 2, 4), da $\gg$ Bog bude sve u svemu « (1 Kor 15, 28). Kao što je svaki čovjek kao pojedinac u Božjem naumu ljubavi još prije postanka svijeta u Kristu izabran da bude osoba Božje prijateljske blizine (usp. Ef 1, 4-5), tako je po istom naumu ljubavi i svaki bračni par muža i žene predviđen da bude Božjim prebivalištem. U tu svrhu Isus Krist od bračnoga zajedništva muža i žene učinio je sakrament svoga jedinstva i ljubavi s Crkvom (usp. Ef 5, 21-33).

Čovjek je stvoren za ljubav. ${ }^{72}$ Već smo istaknuli kako tamo gdje se iskreno, istinito i sebedarno ljubi, tamo je i Bog na djelu. Bog se sigurno objavljuje i u ljubavi naravne

\footnotetext{
${ }^{71}$ Isto.

${ }^{72}$ Usp. AL, br. 129.
} 
ženidbe. Kako u svom osvrtu na pobudnicu Amoris laetitia primjećuje nadbiskup Hranić: »Sakramentalnost kršćanske ženidbe, prema papi Franji, proizlazi, prije svega, iz naravnog reda, iz same naravi ljudske ljubavi. Vjernost, jednost (isključivost), nerazrješivost i plodnost bračnog veza, odnosno ženidbe, oznake su svake iskrene ljudske ljubavi; proizlaze iz naravnoga reda i ukorijenjene su u 'prirodnom nagnuću ljudske osobe' (usp. AL 123). Kao takve, one su sastavnice i sakramentalne ženidbe dvoje kršćana. ${ }^{73}$ Ta naravna svojstva ženidbe, koja ujedno predstavljaju supružničko dobro (bonum coniugum), ${ }^{74} \mathrm{u}$ svjetlu Kristova odnosa prema Crkvi dobivaju novo značenje, konačni smisao i svrhu, pa se, imajući pred očima upravo taj kristocentrični ključ, u pobudnici kaže kako se naravnu ženidbu u punini može razumjeti tek u svjetlu njezina sakramentalnoga dovršenja: »tek usmjerivši pogled na Krista može se do kraja spoznati istina o ljudskim odnosima. ${ }^{75}$

Imajući na umu naravnu osnovu i svojstva ženidbe, u pobudnici se iskazuje poštovanje prema svjedočanstvu bračnih drugova koji ne žive u sakramentalnoj ženidbi, ali su se dokazali ne samo $\gg$ u ustrajnosti već nastavljaju zajednički projekt i čuvaju ljubav $\ll^{76}$. To, prema pobudnici, »otvara vrata pozitivnom, toplom pastoralnom pristupu, koji omogućuje postupno produbljivanje zahtjevâ evanđelja $\ll^{77}$. Ženidbu koja je sklopljena samo građanski, kao i neobveznu životnu zajednicu, kada je u njoj postignuta određena stabilnost javno preuzetom obvezom, kada je obilježena dubokom osjećajnom povezanošću partnera, kada postoji odgovornost za djecu, kao i sposobnost da se izdrži u kušnjama, »može ju se promatrati kao klicu koju treba pratiti u razvoju prema sakramentu ženidbe $\ll^{78}$. $\gg \mathrm{U}$ svakom slučaju, 'svim tim situacijama treba prići konstruktivno, pokušati ih pretvoriti u hod prema punini ženidbe i obitelji u svjetlu evanđelja. Riječ je o tome da ih se prihvaća i prati sa strpljivošću i osjetljivošću.' «99 Iz tih se riječi također može iščitati kako je svrha pastoralnoga hoda koji papa Franjo u pobudnici predlaže »integracija punine Kristova otajstva o braku i obitelji u život svakoga bračnoga para $\ll^{80}$.

\footnotetext{
${ }^{73}$ Đ. HRANIĆ, Ženidba: prirodni poredak prožet otkupiteljskom milošću, 2.

${ }^{74}$ Usp. AL, br. 77.

${ }^{75}$ Isto. Tu se još kao potkrjepa navode riječi iz pastoralne konstitucije Drugoga vatikanskoga koncila Gaudium et spes: »Otajstvo čovjeka stvarno postaje jasnim jedino u otajstvu utjelovljene Riječi. (...) Krist, novi Adam, u samoj objavi Oca i njegove ljubavi potpuno otkriva čovjeka njemu samom i objavljuje mu njegov uzvišeni poziv.« (GS, br. 22).

${ }^{76} \mathrm{AL}$, br. 38.

${ }^{77}$ Isto.

${ }^{78}$ Isto, br. 293.

${ }^{79}$ Isto, br. 294.

${ }^{80}$ H. VARGIĆ, Amoris laetitia: vjernost ili lom?, 123.
} 
Međusobna ljubav i bračna plodnost po kojima muž i žena kao par ostaju neizbrisivo bogoliki, stvoreni na sliku i priliku Boga stvoritelja (usp. Post 1,27), u velikom otajstvu Kristove ljubavi za Crkvu (usp. Ef 5, 32), u koje uključuje sakrament ženidbe, dobivaju svoju milosnu puninu, trinitarni, kristološki i ekleziološki sadržaj: »Od Krista po Crkvi, ženidba i obitelj primaju nužnu milost za svjedočenje Božje ljubavi i življenje zajedništva. $\ll{ }^{81}$ Kako je već istaknuo Ivan Pavao II., bračni su drugovi za Crkvu trajan podsjetnik onoga što se zbilo na križu: »Oni su jedan za drugoga i za svoju djecu živi svjedoci spasenja kojega ih sakrament čini dionicima. $\ll^{82}$

\section{Zaključak}

Prema apostolskoj pobudnici Amoris laetitia naravnu ženidbu u odnosu prema sakramentalnoj treba promatrati kao prirodni, naravni temelj, otvoreni početak, kao $\gg$ sjeme koje još uvijek čeka da sazrije $\ll^{83}$, odnosno kao klicu »koju treba pratiti prema sakramentu ženidbe $\ll^{84}$. $\gg$ Sjemenke Riječi $\ll^{85}$ koje se kriju u naravnoj ženidbi u susretu s Kristovim otajstvom spasenja i ljubavi mogu izniknuti i izrasti u milosno stablo života. U svjetlu takvih milosnih mogućnosti prema kojima naravna ženidba iznutra teži, ona zaslužuje iskreno poštovanje, strpljivu i radosnu nadu. A opet iz takve perspektive, sakramentalna ženidba nije tek »društveni ugovor, prazni ritual ili samo vanjski znak opredijeljenosti $\ll^{86}$, slučaj, običaj, obveza, dužnost, jaram, nego radije sveta želja, čežnja, u konačnici, veliki dar, zvanje (poslanje) i dragocjeni znak koji se priželjkuje i za koji se temeljito priprema i moli, jer se s njime, u konačnoj perspektivi vječnoga života, uza sve neizbježne životne, bračne i obiteljske križeve, može živjeti vjerno, radosno i zahvalno. ${ }^{87}$ Krist kršćanskim supružnicima već na ovome svijetu u radostima njihove ljubavi i obiteljskoga života daje predokus gozbe Jaganjčeve. ${ }^{88}$

\footnotetext{
${ }^{81}$ AL, br. 63.

${ }^{82}$ Isto, br. 72; FC, br. 94.

${ }^{83}$ AL, br. 76.

${ }^{84}$ Isto, br. 239.

${ }^{85}$ Usp. isto, br. 77. Pojam koji je korišten u dekretu Drugoga vatikanskoga koncila o misijskoj djelatnosti Crkve Ad gentes, u br. 11, a odnosi se na druge kulture (na otkrivanje sjemenki Riječi koje se tu kriju), Papa smatra da je primjenjiv i na bračnu i obiteljsku zbiljnost (usp. AL, br. 77).

${ }^{86}$ Isto, br. 72.

${ }^{87}$ Usp. CV, br. 260. Papa citira svoj govor mladima Umbrije u Asizu, 4. listopada 2013.: »Volim misliti kako su dvoje kršćana koji sklapaju ženidbu prepoznali u svojoj ljubavnoj priči Gospodinov poziv, poziv da od dvoga - muško i žensko - stvore jedno tijelo i jedan jedini život. Sakrament ženidbe obavija ovu ljubav Božjom milošću, ukorjenjuje ju u samoga Boga. Tim darom i sigurnošću tog poziva može se ići naprijed kroz život sigurna koraka, bez straha od bilo čega, može se, zajedno, nositi sa svime! «

${ }^{88}$ Usp. KKC, br. 1642.
} 


\title{
(CO)RELATION OF NATURAL AND SACRAMENTAL MARRIAGE ACCORDING TO THE APOSTOLIC EXHORTATION AMORIS LAETITIA
}

\author{
Anton TAMARUT*
}

Summary: The article presents and analyses the (co)relationship of natural and sacramental marriage according to the Apostolic Exhortation Amoris letitia. The first chapter draws attention to the fact that the very gospel of the family, within which the marriage covenant occupies a central place, is a historical and eschatological reality; it has its natural and sacramental level, its relief and dynamic history, gradual growth and development. The second chapter presents and analyses man's creation in the image of God wherein lies the foundation of natural marriage. The expression the image of God is brought into direct connection with the pair $\gg$ male and female. $\ll$ The third chapter draws attention to sin, that is, to the mystery of Christ's mystery of salvation as the basis for understanding the sacramentality of marriage. Reference is made to the central meaning of Jesus Christ - the image of God in the renewal of marriage and family, and the sacramental meaning of marriage and family is analysed in detail. The sacrament of marriage is viewed under the aspect of a gift, a sign and a vocation, or mission. The fourth chapter is devoted to the very (co)relationship between natural and sacramental marriage. Natural marriage in relation to the sacramental is seen as a natural foundation, an open beginning, as $\gg$ seeds that are still waiting to grow $<(A L, 76)$, or as a sprout that $\gg$ should be lead to the sacrament of marriage $\ll(A L, 293)$.

Keywords: natural marriage, sacramental marriage, family, man - the image of God, the Most Holy Trinity, Jesus Christ, the Church.

\footnotetext{
* Full Prof. Anton Tamarut, Ph. D., Catholic Faculty of Theology, University of Zagreb, Vlaška 38, P. O. box 432, 10000 Zagreb, Croatia, tamaruta@kbf.hr
} 